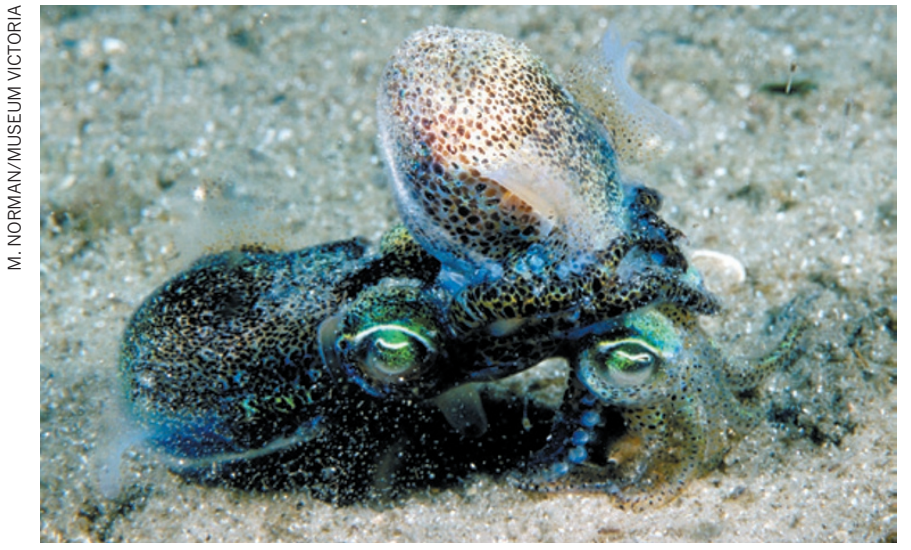

foraging opportunities.

Amanda Franklin and her colleagues at the University of Melbourne in Victoria, Australia, collected wild dumpling squid (Euprymna tasmanica; mating male and female pictured). They tested the creatures' swimming endurance in a tank with a constant current, before and after the squid mated. Mating halved the time taken for males and females to become exhausted, but both regained their energy within 30 minutes of copulation.

Knowing this cost could contribute to a better understanding of the evolution of reproductive behaviours, such as promiscuity, in squid, the researchers say.

Biol. Lett. http://dx.doi. org/10.1098/rsbl.2012.0556 (2012)

\section{NEUROSCIENCE}

\section{Light control in monkey brains}

Using a technique that makes it possible to control the activity of specific engineered neurons with light, neuroscientists have modified behaviour in primates.

Optogenetics can help researchers to figure out the role of individual neurons, but it has previously been used to control behaviour only in rodents and invertebrates. Wim Vanduffel at Harvard Medical School in Boston, Massachusetts, and his colleagues genetically modified neurons in the premotor and prefrontal cortex brain regions of two rhesus monkeys, so that the neurons fired when blue light was delivered into the brain by an optical cable. Stimulating these neurons as the monkeys performed an eye-movement task changed the latencies of eye movements in both animals. Functional magnetic resonance imaging revealed that the stimulation induced distinct patterns of brain activity during the task. Curr. Biol. http://dx.doi. org/10.1016/j.cub.2012.07.023 (2012)

\section{PALAEOANTHROPOLOGY}

\section{Resilient to natural disasters}

A study of ancient volcanic ash found at key archaeological sites suggests that Neanderthals (pictured) and early modern humans were more resilient to climate change and natural disasters than is often assumed.

John Lowe at the Royal Holloway University of London in Egham, UK, and his colleagues analysed microscopic shards of volcanic ash from a major eruption that occurred in Europe some 40,000 years ago. The volcano spewed so much climate-cooling ash that the event probably created

COMMUNITY CHOICE

\title{
Aerosols keep down monsoon rain
}

\section{7highly Read \\ on www.agu.org the week of 23 July}

Tiny airborne particles called atmospheric aerosols tend to reduce summer monsoon rainfall over most of South Asia.

Dilip Ganguly and his colleagues at the Pacific Northwest National Laboratory in Richland, Washington, used a simplified atmosphere-ocean model to simulate the effects of changes in the levels and composition of atmospheric aerosols - from local and distant sources - on South Asia's mean monsoon rainfall. Increased local emissions of aerosols such as black carbon - which absorbs sunlight and produces a warming effect that tends to reduce cloud cover — weakened the monsoon rains in most of South Asia. Aerosols from outside Asia also contributed to the overall reduction in rainfall.

Only over northwest India, where aerosol emissions from local forest and grass fires are thought to be decreasing, did the mean summer monsoon rainfall increase.

J. Geophys. Res. http://dx.doi.org/10.1029/2012JD017508 (2012) winter-like conditions. Because the researchers found the ash at several archaeological sites in Europe and North Africa, they were able to link events in Neanderthal and human evolution with the timing of climatic changes. Early modern humans started to displace

Neanderthals from parts of Europe before the eruption and subsequent cooling, and their activities appear to have been unaffected by these events. Indeed, in parts of central and eastern Europe, Neanderthals seem to have become extinct well before the eruption occurred. Early modern humans probably placed greater pressure on Neanderthals than did volcanic eruptions or climate change, the researchers suggest.

Proc. Natl Acad. Sci. USA http://dx.doi.org/10.1073/ pnas.1204579109 (2012)

\section{Gene fix repairs hearing}

Gene therapy has restored hearing for up to 18 months in mice that were born deaf.

The animals are missing the gene that encodes the protein VGLUT3. Lack of VGLUT3 renders inner hair cells of the ear's cochlea incapable of sending electrical signals to the brain. Lawrence Lustig at the University of California, San Francisco, and his team used a virus to deliver the Vglut3 gene into the cochleas of these mice. After one week, the researchers detected auditory responses in the creatures' brains, and within two weeks, the animals showed an increased startle response to sound.

The results could bode well for humans, the researchers suggest, because VGLUT3 is also associated with a rare form of human deafness. Neuron 75, 283-293 (2012)

\section{DNATURE.COM}

For the latest research published by Naturevisit:

www.nature.com/latestresearch 